\title{
The Hague Convention: Pros, Cons and Potential
}

\section{Citation}

Elizabeth Bartholet, The Hague Convention: Pros, Cons and Potential, Pepperdine University, Herbert \& Elinor Nootbar Institute On Law, Religion \& Ethics, Breakout Session II, "The Hague Convention On Intercountry Adoption: Past, Present \& Future: The Hague Convention: Pros \& Cons To Date; Potential For The Future" (Feb. 8, 2013).

\section{Permanent link}

http://nrs.harvard.edu/urn-3:HUL.InstRepos:10777663

\section{Terms of Use}

This article was downloaded from Harvard University's DASH repository, and is made available under the terms and conditions applicable to Open Access Policy Articles, as set forth at http:// nrs.harvard.edu/urn-3:HUL.InstRepos:dash.current.terms-of-use\#OAP

\section{Share Your Story}

The Harvard community has made this article openly available.

Please share how this access benefits you. Submit a story.

Accessibility 
$9 / 5 / 2013$

\title{
THE HAGUE CONVENTION: PROS, CONS AND POTENTIAL
}

\author{
Elizabeth Bartholet ${ }^{1}$
}

\section{INTRODUCTION}

The Hague Convention on Intercountry Adoption was supposed to help children. It was supposed to help unparented children get what they most need - nurturing parents and permanent homes.

To date the Hague has failed. Indeed to date it has functioned primarily to prevent children from getting the homes they need because it has been responsible for shutting down rather than opening up international adoption opportunities.

But the Hague Convention's potential remains alive. The future is open for it to achieve what it was designed to achieve.

\section{PROS \& CONS TO DATE}

\footnotetext{
${ }^{1}$ Professor of Law and Faculty Director of the Child Advocacy Program, Harvard Law School. This chapter is a slightly revised version of a talk given at a panel entitled "The Hague Convention on Intercountry Adoption: Past, Present \& Future," at a conference on "Intercountry Adoption: Orphan Rescue or Child Trafficking?," sponsored by the Herbert \& Elinor Nootbar Inst. on Law, Religion \& Ethics, at Pepperdine University, February 8-9, 2013. For other of my work on international adoption see http://www.law.harvard.edu/faculty/bartholet/pubs.php. Documentation for the claims made in this chapter is contained in various of the articles cited on this website including in particular: Bartholet, Intergenerational Justice for Children: Restructuring Adoption, Reproduction \& Child Welfare Policy, J. Law \& Ethics of Human Rights (forthcoming 2013-14), http://www.law.harvard.edu/faculty/bartholet/IA-IntgenerJusticeDraftArticle6-12-13\%20(2).pdf; Bartholet and Smolin, The Debate, chapter in INTERCOUNTRY ADOPTION: POLICIES, PRACTICES, and OUTCOMES, 233 (Ashgate Publishing 2012); Bartholet, Ratification by the United States of the Convention on the Rights of the Child: Pros and Cons from a Child's Rights Perspective, 633 The ANNALS of Amer. Acad. Political and Social Science 80, Special Issue, The Child as Citizen (2011); Bartholet, International Adoption: The Human Rights Position, 1 Global Policy 91 (2010) ; Bartholet, International Adoption: The Child's Story, 24 Ga. St. U. L. Rev. 333 (2008); Bartholet, International Adoption: Thoughts on the Human Rights Issues, 13 Buff. Hum. Rts. L. Rev. 151 (2007).
} 


\section{The Law on the Books}

The language of the Hague Convention represents as a formal matter a huge step forward for children in international law. The key law governing international adoption prior to this was the Convention on the Rights of the Child (CRC). The CRC contained "subsidiarity" provisions which created a preference for in-country foster care and for "other suitable care" over international adoption. These provisions are seriously hostile to children's interests, a sad irony given that the CRC is supposed to stand as the ultimate legal vindication of child rights. The evidence is overwhelming that permanent adoption, whether domestic or international, serves child interests far better than foster care. The CRC's ambiguous language about "other suitable care" has been used as justification for preferring institutional care over international adoption, and of course the evidence is again overwhelming as to how destructive institutional care is for children. $^{2}$

The Hague Convention's subsidiarity provisions limit the in-country placement preference to domestic adoption, and other true family care. There is no indication in the language that paid foster care should qualify as the kind of family care preferred over international adoption. ${ }^{3}$

The Hague Convention also represents affirmation by the international community that international adoption can and should be done in ways that serve child best interests, and that respect birth parent rights. It creates new safeguards said to help ensure that these goals are met. Accordingly the Hague could embolden national leaders who want to do the right thing by enabling their nation's children to be placed in good adoptive homes abroad, but might feel afraid of being accused of doing the wrong thing. The Hague provides such leaders some protection against simplistic claims that international adoption equates with child exploitation.

On the negative side, the Hague Convention represents a huge lost opportunity. During the negotiations about the form the Convention would take there was talk about the importance of designing this new law to facilitate international adoption, enabling cooperation between sending and receiving nations so that more children could be placed, and placed earlier in life. However opponents of international adoption fought the inclusion of any facilitating language, and won.

The Law on the Ground

\footnotetext{
2 See, e.g., Bartholet, Ratification by the United States of the Convention on the Rights of the Child, supra $\mathrm{n} .1$ at 94-97 (discussion of the Convention's problematic subsidiarity provisions related to international adoption).

${ }^{3}$ See, e.g., id at 97 (discussion of the Hague's subsidiarity provisions). I interpret the Hague reference to family care to mean true loving, nurturing, committed family care, not paid foster care, or at least not as a general matter, since paid foster care does not ordinarily provide the equivalent of true family care.
} 
The actual influence of the Hague Convention to date has been entirely negative. It has operated to restrict and reduce international adoption.

At the same time there is no evidence that it has operated in any significant way to provide greater protection for children or birth parents against exploitation. Domestic and international law designed to provide such protection already existed prior to the Hague. It is not clear that the Hague's new requirements add any real protection.

The Hague's negative impact is a result of the fact that policy makers have ignored its positive aspects, have misinterpreted it as more restrictive than it was intended to be, and have enforced its new requirements without helping enable countries to satisfy those requirements.

Thus many opponents of international adoption have simply ignored the Hague's step forward in recognizing international adoption as a good option for children. UNICEF, the U.N. Committee on the Rights of the Child, and others defer to the earlier Convention on the Rights of the Child in its preference for in-country foster care over out-of-country adoption. They ignore the international law principles indicating that in the event of conflict the later and more specific treaty should govern. ${ }^{4}$

Opponents have used the fact that countries must take action to ratify the Hague as an opportunity to urge legislation imposing new restrictions on international adoption. They have misrepresented the Hague Convention's requirements, telling countries that to comply with the Hague they must eliminate private adoption intermediaries. UNICEF and the Hague Permanent Bureau have both taken this position, despite the fact that the U.S. fought hard in the Hague negotiations to ensure that the Hague would allow the continued use of private intermediaries. Peter Hayes, an academic expert on international adoption, has documented in a detailed and persuasive article this deliberate distortion of the Hague Convention, and the fact that it was only after the U.S. was safely on board with its ratification of the Convention that the Hague Permanent Bureau changed its position to one claiming that the Convention eliminated private intermediaries. ${ }^{5}$ The net result of this misuse of the Hague has been the near-elimination of international adoption throughout Central and South America, where private intermediaries were known by UNICEF and others to serve as the lifeblood of such adoption. ${ }^{6}$

\footnotetext{
${ }^{4}$ Id at 97.

${ }^{5}$ Hayes, The Legality and Ethics of Independent Intercountry Adoption Under the Hague Convention, 25 Intl. J. Law, Policy and the Family288 (2011).

${ }^{6}$ Bartholet, International Adoption: The Child's Story, supra n. 1 at 341-42 (2008).
} 
Policy-makers have misused the subsidiarity principle built into the Hague Convention to unnecessarily limit international adoption. The Convention simply requires that in-country adoption and other true family care be preferred over out-of-country adoption. But subsidiarity has been used to justify new requirements that children be held for significant periods of time while in-country homes are supposedly recruited, and other requirements making international adoption yet more of a last-last resort.

The United States has also misused the Hague to restrict international adoption. It has pushed countries to ratify the Hague, threatening not to work with certain countries in the absence of ratification. And then once a country ratifies, the U.S. has often shut down its international adoption program, claiming that the country has failed to comply adequately with Hague requirements.

Finally, there is the issue of unintended consequences. The Hague Convention creates new requirements that any ratifying country must satisfy before its international adoptions are lawful. These requirements include the creation of a Central Authority, and the adoption of a variety of procedures which for many countries will be new. ${ }^{7}$ Countries may decide to ratify as they are encouraged to do, without thinking through what it would take to comply. It took the U.S. many years to develop the legislation and related infrastructure needed to implement the Hague. For impoverished countries implementation can be a daunting task. Ratification may result in the suspension for many years of international adoption programs which had been working perfectly well, simply because countries cannot get it together to create the infrastructure needed for Hague implementation.

\section{POTENTIAL FOR THE FUTURE}

Despite the disappointments of the Hague Convention to date, the future is open, and the potential for the Convention to be a positive force is alive. It is up to the policy makers to realize this potential, and up to those of us who believe in international adoption to push the policy makers to do so.

I will focus here on the United States Government and some of what it might do to enable the Hague Convention to work as it could to help children.

First, the United States could advocate for recognition that the Hague Convention we fought hard to create is the governing law to the degree it conflicts with the Convention on the Rights

\footnotetext{
${ }^{7}$ See, e.g., Bartholet, International Adoption: Thoughts on the Human Rights Issues, supra n. 1, at 176.
} 
of the Child. We could advocate for the important Hague principle that international adoption trumps all in-country placement options save for adoption.

Second, the United States could advocate for proper interpretation of the Hague, an interpretation allowing private intermediaries, something that we again fought hard for in the context of the Hague negotiations. The United States could help educate other countries ratifying and implementing the Hague that they do not have to follow the wrongful interpretation being promoted by the Hague Permanent Bureau and UNICEF.

Third, the United States could advocate for an appropriate definition of Hague subsidiarity, namely one that prefers in-country adoption only when it can be accomplished with no delay in placement. Subsidiarity should be defined and limited by a Concurrent Planning strategy, in which countries plan simultaneously both for domestic and international adoption, preferring domestic over international placement only when an equally qualified domestic home is immediately available. ${ }^{8}$

And finally, the United States could focus on helping countries implement the Hague Convention properly, rather than on penalizing their compliance failures with international adoption shut-downs.

The Hague Convention could in the future be what its drafters and our Hague negotiators intended, a step forward for children, enabling international adoption to better serve their interests.

Whether it fulfills this potential is up to the policy-makers, and to us.

\footnotetext{
${ }^{8}$ Nothing in the Hague Convention prevents this. The subsidiarity language says only that "due regard... be paid to the desirability of continuity... and to the child's ethnic, religious, cultural and linguistic background," and prioritizes in-country adoption and other "family care" over international adoption. Bartholet, Ratification by the United States of the Convention on the Rights of the Child, supra n. 1 at 97.
} 